\title{
Pertarungan Ideologi Realisme Sosialis dan Feodalisme Religis dalam Novel Midah Simanis Bergigi Emas Karya Pramoedya Ananta Toer
}

\author{
Moh. Muzakka \\ Fakultas Ilmu Budaya UNDIP \\ muzakkamoh@yahoo.co.id
}

\begin{abstract}
Literary work is a means for authors to offer various ideologies to their readers. Through literature, the author can influence the views of life and or ideology of the reader. From the inter-group conflict that was built into the structure of literary works, the author can fight for the ideology he adheres to. This short article intends to uncover the ideological struggle in Pramoedya Ananta Toer's novel Midah Simanis Bergigi Emas using the analysis of Gramsci's hegemony. The analysis shows that the Midah Simanis Bergigi Emas novel offers three ideologies namely the ideology of feudalism (which controls), the primitive ideology of coastal culture (which is mastered), and the ideology of socialist realism (which is championed). Because in the novel the two contrasting cultures are seen as bad culture, the culture of socialist realism is the most ideal.
\end{abstract}

Keywords: Ideology, oastal, priyayi, hegemony, socialist realism.

\section{Intisari}

Salah satu cara menawarkan ideology dengan cerdas adalah melalui karya sastra. Sebab, karya sastra yang ditulis dengan baik oleh pengarang dapat mempengaruhi pikiran pembaca. Semakin pembaca menyukai karya sastra yang dibacanya, maka pengarang dapat memengaruhi dan mengubah ideologi pembaca. Melalu konflik yang diciptakan pengarang melalui tokoh-tokohnya dalam karyanya, pengarang dapat memberikan alternatif ideologi yang diyakininya pada pembacanya. Artikel pendek ini mencoba untuk mendeskripsikan tawar-menawar ideologi dalam novel Midah Simanis Bergigi Emas karya Pramoedya Ananta Toer dengan cara menganalisisnya dengan teori hegemoni Gramsci. Dari kajian mendalam diperoleh hasil bahwa dalam novel Midah Simanis Bergigi Emas ditemukan tiga ideologi yang berkonsensus yakni ideologi feodalisme (yang mendominasi), ideologi primitif kultural pesisiran (yang tersubordinasi), dan ideologi realisme sosialis (yang dibangkitkan). Karena pengarang dalam novel ini menunjukkan bahwa budaya yang dominan dan residual ditampilkan kurang baik, maka pengarang menawarkan ideologi realisme sosialis sebagai ideologi yang paling ideal.

Kata Kunci: Konsensus, ideologi, hegemoni, feodalisme, realisme sosial. 


\section{Pendahuluan}

Salah satu media ampuh untuk menanamkan sebuah ideologi adalah melalui karya sastra. Pengarang yang menganut ideologi tertentu dapat mengampanyekan melalui karya sastra yang diciptakannya. Ia dapat menanamkan nilai-nilai dan ajaran ideologi diyakininya secara halus dan estetis pada pembacanya. Dengan ideologi yang dianutnya, ia dapat menawarkan pada pembaca dengan cara membangun konflik-konflik dalam struktur karya yang ditulisnya. Dari konflik-konflik yang dibangun itulah, ia dapat memperjuangkan ideologi alternatif untuk melawan ideologi yang tengah mendominasi atau yang berkuasa maupun ideologi kultural yang kian menghilang. Sebab, hakikatnya ideologi alternatif yang dibangkitkan pengarang itu untuk memberikan solusi terhadap dominasi ideologi yang sedang berkuasa atas ideologi residual kultural. Terkait persoalan itu, Mussaif (2018: 69) mengungkapkan bahwa pertarungan ideologi dalam sebuah karya sastra harus dianalisis dengan cermat dan mendalam. Sebab, dari analisis mendalam tersebut dapat dideskripsikan bentuk dan wujud beberapa ideologi yang ditawarkan dan dibangkitkan pengarang dalam menghadapi ideologi-ideologi yang tengah berkuasa.

Ideologi pengarang sangat dipengaruhi oleh beberapa hal; di antaranya adalah latar belakang pendidikan, agama, suku bangsa, bahasa, ormas, dan orpol yang dianut dan diikutinya. Dari kesamaan ideologi itulah sangat memungkinkan pengarang bergabung dalam kelompok-kelompok pengarang. Hal demikian ini telah terjadi dalam lintasan sejarah sastra Indonesia sejak awal mula munculnya, saat tumbuh dan berkembangnya hingga sekarang. Hadirnya kelompok lembaga kesenian dan budaya seperti LKN, Lesbumi, dan Lekra pada awal kemerdekaan Republik Indonesia merupakan bukti munculnya beberapa kelompok pengarang yang menyatu dalam aliran atau paham tertentu, termasuk dalam partai politik tertentu. Lembaga Kebudayaan Nasional (LKN) merupakan organisasi kebudayaan yang didirikan PNI, Lesbumi didirikan NU, dan Lembaga Kebudayaan Rakyat (Lekra) didirikan PKI. Begitu juga hadirnya sanggar-sanggar sastra, komunitas sastra seperti Forum Lingkar Pena yang sampai saat ini masih cukup kuat sangat terkait dengan paham tertentu.

Hadirnya Lekra yang kemudian menjadi organisasi terlarang pada masa orde baru sangat menarik untuk dikaji. Sebab, Lekra yang didirikan PKI itu berperan untuk 
menyebarkan ideologi realisme untuk menghadapi ideologi lain seperti feodalisme, kapitalisme, bahkan aliran dan ajaran agama tertentu. Keberadaan Lekra pada tahun 50-an hingga 60-an sangat mempengaruhi keberhasilan PKI dalam menarik masyarakat. Dengan paham realisme sosialis itulah kebudayaan, keseniaan, dan kesusastraan dikembangkan.

Salah seorang tokoh Lekra yang berpengaruh dan paling konsisten dengan paham realisme sosialis adalah Pramoedya Ananta Toer. Di samping komitmennya terhadap lembaganya sangat kuat, yakni Lekra, ia pun sangat meyakini paham yang diikutinya. Meskipun dari aktivitas berkeseniannya menyebabkan ia lama sangat lama hidup di penjara pada rezim Soekarno dan Soeharto, sepanjang menjalani hukuman itu pun ia tidak pernah berhenti menulis novel. Sebagai tahanan politik, ia pun tetap berkarya dengan menyuarakan ideologi realisme sosialis, bahkan sampai menjelang ajal pun ia tidak berhenti menulis. Sepanjang karier kepenulisannya, Pramoedya Ananta Toer telah menghasilkan lebih dari 50 karya dan beberapa di antaranya telah diterjemahkan sekurangkurangnya dalam 41 bahasa asing (Mussaif, 2018).

Hampir dalam semua karya sastra yang ditulisnya, Pramoedya Ananta Toer menawarkan ideologi realisme sosialis yang diperjuangkannya, sebab menurutnya, ideology tersebut paling ideal untuk masyarakat. Dalam novel-novel yang diciptakannya itu, Pramoedya Ananta Toer selalu menunjukkan fenomena dan kasus-kasus yang terjadi bahwa paham realisme sosialis lebih baik dari ideologi-ideologi yang lain, seperti ideologi feodalis, kapitalis, maupun ideologi yang berbasis agama. Sebab menurutnya, ideologi realisme sosialis menempatkan manusia setara dalam kelas sosial, termasuk setara dalam gender. Sementara, ideologi lain dipandang sebaliknya, yakni cenderung mengelompokkan masyarakat dalam kelas sosial tertentu seperti priyayi-abdi, majikan-budak, lelakiperempuan, kaya-miskin, dan seterusnya (bdk. Mussaif, 2014; Mussaif, 2018).

Bertolak dari latar belakang tersebut, penulis ingin mengungkap pertarungan ideologi dalam sebuah novel karya Pramoedya Ananta Toer. Mengingat karya Pramoedya Ananta Toer cukup banyak, maka dalam tulisan akan dikaji sebuah novel yang kurang diperhatikan pemerhati sastra yakni novel Midah Simanis Bergigi Emas (2017). Untuk mengungkap pertarungan ideologi dalam novel tersebut, akan digunakan pendekatan sosiologi sastra, khususnya perspektif hegemoni Gramsci. Sebab, Gramsci dengan cerdas 
berasumsi bahwa dunia ide itu bukan semata-mata merupakan ekspresi struktur kelas yang bersifat material, melainkan ide itu menjadi salah satu dari kekuatan material (Faruk, 1994: 61).

Gramsci menilai bahwa dunia ide, kultur, dan superstruktur bukan semata-mata sebagai refleksi dari struktur kelas (infrastruktur) yang bernilai material, tetapi ia menilai hal tersebut menjadi salah satu dari kekuatan material itu sendiri. Dalam kedudukannya sebagai kekuatan material itu, dunia gagasan sangat potensial dalam mengatur dan memengaruhi masyarakat di dunia ini untuk bergerak dan beraktivitas (Faruk, 1994: 6162). Konsep hegemoni ini sangat halus dalam proses kerjanya, yakni melalui tawarmenawar atau konsensus-konsensus bukan dengan cara memaksakan.

Senada dengan Gramsci, Raymond William menegaskan bahwa hegemoni merupakan suatu proses, bukan suatu bentuk dominasi yang ada secara pasif, melainkan sesuatu yang harus terus menerus diperbarui, diciptakan kembali, dipertahankan, dan dimodifikasi. Terkait dengan persoalan itu, William menyebutkan bahwa ideologi dalam sastra (aktivitas budaya) dapat dikelompokkan menjadi tiga, yaitu ideologi dominan yaitu ideologi yang berkuasa; ideologi bangkit yaitu ideologi yang diperjuangkan pengarang, dan ideologi residual atau endapan yaitu ideologi yang pernah ada sebelum dikuasai ideologi dominan (Faruk, 1994: 78-79).

Konflik yang terjadi dalam karya sastra lebih merupakan upaya menawarkan ideologi baru yang diperjuangkan pengarang untuk menyerang ideologi hegemonik yang dominan. Penawaran ideologi yang diperjuangkan pengarang itu pada umumnya dilatarbelakangi oleh benturan ideologi residual dengan dengan ideologi hegemonik yang dominan. Bertolak dari kerangka pemikiran tersebut, dalam tulisan ini penulis akan mencoba mendeskripsikan pertarungan ideologi yang muncul dalam Novel Midah Simanis Bergigi Emas.

\section{Metode Penelitian}

Objek material yang dijadikan bahan kajian adalah novel Pramoedya Ananta Toer yang berjudul Midah Simanis Bergigi Emas. Adapun aspek yang menjadi fokus kajiannya adalah pertarungan ideologi dalam novel tersebut. Mengingat fokusnya pertarungan ideologi dalam karya sastra, maka pendekatan yang digunakan dalam mengkaji novel 
Pramoedya ini adalah pendekatan sosiologi sastra, yakni pendekatan yang menitikberatkan pada hubungan karya sastra dengan nilai-nilai sosial yang berlaku pada pengarang dan pembaca (Damono, 2010 bdk. Faruk, 1995).

Terkait dengan persoalan tersebut, maka metode pengumpulan data dalam penelitian ini adalah studi pustaka. Data primer dalam tulisan ini diperoleh dari objek materialnya yaitu novel Midah Simanis Bergigi Emas karya Pramoedya Ananta Toer, sedangkan jika ditemukan dan tersedia data lain dari penelitian sebelumnya maka dapat dimanfaatkan sebagai data pendukung (data sekunder).

Terkait dengan pengkajian aspek pertarungan ideologi dalam novel Midah Simanis Bergigi Emas itulah penulis mencoba menggunakan perspektif hegemoni Gramscian. Sebab, perspektif ini memandang bahwa karya sastra adalah alat untuk memperjuangkan ideologi yang diyakini, diidealkan, dan diperjuangkan pengarang. Dari kajian hegemoni ini akan dapat diungkap ideologi apa yang diperjuangkan Pramoedya Ananta Toer dalam novel Midah Simanis Bergigi Emas untuk melawan ideologi dominan atau ideologi yang sedang berkuasa.

\section{Hasil dan Pembahasan}

Pramoedya adalah seorang novelis yang sangat konsisten dengan ideologi yang diyakini dan diperjuangkannya, yakni realisme sosialis. Ideologi ini menolak keras terhadap pembagian kelas di masyarakat. Ideologi ini menganggap bahwa dengan munculnya pembagian kelas sosial secara otomatis menimbulkan ketidaksetaraan kelas. Realisme sosialis secara tegas menolak paham kapitalisme, kolonialisme, feodalisme, dan otoritarianisme.

Dalam semua tulisan dan karya sastra yang diciptakannya, Pramoedya selalu menawarkan dan memperjuangkan paham realisme sosialis untuk melawan isme-isme lain. Dalam novel Midah Simanis Bergigi Emas pun ia memperjuangkan ideologinya melawan feodalisme dan otoritarianis.

Berdasarkan teori hegemoni Gramscian ini, konflik yang diciptakan Pramoedya Ananta Toer dalam novel Midah Simanis Bergigi Emas juga bertolak pada pertarungan tiga ideologi, yaitu ideologi primitif, yakni ideologi yang pernah berlaku di masyarakat secara kultural berbalut tradisi; ideologi dominan, yakni ideologi yang tengah berkuasa 
dalam kehidupan masyarakat; dan ideologi bangkit, yakni ideologi yang sedang diperjuangkan sang pengarang. Dalam tulisan pendek ini, penulis mencoba mengidentifikasi ketiga ideologi yang muncul dalam novel tersebut serta memetakan ideologi-ideologi dan pertarungannya dalam struktur sosial yang dibangun pengarang.

\section{Ideologi Residual: kulturalisme Jawa-Islam}

Ideologi primitif atau residual yang muncul dalam novel Midah Simanis Bergigi Emas adalah ideologi kulturalisme Jawa-santri, yakni ideologi yang telah berlangsung lama yang bersifat turun temurun. Sesuai dengan nama-nama tokoh novel yakni Midah, Haji Abdul, Riah, Ahmad, Rodjali secara kultural adalah nama yang berlatar belakang agamis-Islami yang tinggal di Jawa. Kultur masyarakat demikian ini lazim disebut golongan Jawa-santri. Sebutan Jawa-santri di sini mengacu pada tokoh-tokohnya yang memeluk agama Islam, taat beribadah, hingga lagu-lagu yang diputar setiap hari pun lagulagu Arab.

Keluarga tokoh utama pun tergolong berstatus sosial tinggi dan taat beribadah. Namun, watak-watak tokohnya pun berubah saat Midah punya adik lelaki. Semula ayahnya, Haji Abdul, sangat menyayangi dan memanjakan Midah. Setelah kehadiran anak lelaki yang sangat diidamkannya itu, Midah pun tidak diperhatikannya. Bahkan ketika Midah melakukan tindakan-tindakan perlawanan, seperti pergi lama hingga pulang malam pun tidak diperhatikan.

Paham kultural patrilinial masih dipegang kuat oleh keluarga Haji Abdul, yakni bangga punya keturunan lelaki. Meski ia telah mempunyai anak yang cantik, tetapi ia berharap untuk mendapatkan anak lelaki. Hal demikian ini tampak dalam pikiran, harapan, doa, dan kaulnya (Toer, 2003: 11-12).

Kultur patriarki ini dibangung oleh kultur Jawa yang membumi ditambah dengan dogma agama yang dipandang berpihak pada patriarki. Dalam novel Midah Simanis Bergigi Emas inilah Pramoedya membenturkan ideologi kultural dan ideologi feodal yang dianggap kurang ideal dalam tataran kehidupan sosial.

\section{Ideologi Dominan: Feodalisme-Religis}

Ideologi yang dominan (yang berkuasa) dalam novel Midah Simanis Bergigi Emas adalah feodalisme-religis. Ideologi ini disuarakan dan diperankan oleh Haji Abdul, pengusaha 
toko beretnis Jawa yang taat beribadah. Ia adalah kepala keluarga yang sholih, sayang keluarga dan taat beribadah. Sebagai pemimpin keluarga ia pun mengatur keluarga, yakni istri dan anak sesuai dengan kultur dan paham agama yang dianutnya.

Dalam novel, tokoh Haji Abdul digambarkan sebagai orang yang tidak adil dan otoriter dalam memimpin keluarga. Ketidakadilan tokoh ini tampak sekali setelah ia mempunyai anak lelaki. Tokoh Midah yang awalnya sangat disayangi dan dimanjakan serta dididik dalam nuansa Jawa-religis, kurang diperhatikan, dan cenderung dibiarkan. Bahkan meskipun Midah berbuat melanggar aturan seperti keluar rumah dan pulang malam tidak dipedulikannya. Haji Abdul seakan melupakan anak perempuannya dan sangat membanggakan anak lelakinya. Keberpihakan pada lelaki inilah menjadikan tokoh Haji Abdul bersikap tidak adil terhadap perempuan.

Sikap tidak adil tokoh tersebut membuahkan sikap otoriter sehingga kian kuat merepresi tokoh perempuan dalam keluarganya. Dengan menggunakan dogma agama, sebagai pemimpin patriarki, Haji Abdul menjadi kepala keluarga yang sangat tegas. Seluruh anggota keluarganya pun harus mengikuti keinginan dan perintahnya. Sikap demikian, misalnya tampak dalam berkesenian dan pernikahan. Dalam berkesenian keluarganya tidak diperkenalkan dengan kesenian Jawa maupun kesenian etnis lain. Namun, dalam setiap hari yang diperdengarkan lewat gramapunnya hanya lagu-lagu Arab (Mesir), terutama lagu-lagu yang dinyanyikan Ummi Kulsum. Sebab, kesenian selain nonArab dianggap haram olehnya. Data demikian tampak pada sikapnya yang tegas dengan nada marah saat Midah memutar lagu keroncong di rumahnya, bahkan beberapa kepingan piringan hitam yang dibelinya pun dihancurkan Haji Abdul (Toer, 2003: 18-19).

Sikap otoriter kaum patriarki tampak pada tokoh Haji Abdul dalam menjodohkan dan menikahkan anaknya, Midah, dengan orang yang tidak dikenal dan disayanginya. Dalam novel ini, Midah diperjodohkan dengan orang paruh baya, kaya, bergelar haji, dan beristri banyak. Sikap otoriter sang ayah demikian ini ditunjukkan secara jelas dalam novel ini. Midah, sebagai anak yang taat dan takut pada sang ayah tak kuasa menolaknya. Ia pun menjalani perintah sang ayah, menikah dengan Haji Terbus dari Cibatok yang tidak bujang dan sudah beristri banyak. Dengan terpaksa ia menjalani pernikahan itu meskipun kemudian setelah beranak satu ia pun pergi meninggalkan suaminya yang juga bersikap otoriter. Sikap otoriter kaum patriarki dalam novel tersebut, di antaranya tampak 
dijodohkan dengan paksa oleh ayahnya pada Hadji Terbus, orang tua yang tidak lagi perjaka, bahkan istrinya pun di seluruh Cibatok sudah sangat banyak (Toer, 2003: 20-21).

\section{Ideologi Bangkit: Realisme Sosialis}

Ideologi yang diperjuangkan (bangkit) dalam novel Gadis Pantai ini adalah ideologi realisme sosialis. Secara umum realisme sosialis menginginkan keharmonisan antara kenyataan dan idea. Kenyataan harus dinyatakan sebagai mana adanya, menurut proposisi aslinya, sementara idea harus disandarkan pada konteks kondisi objektif. Hal yang paling prinsip dari semuanya adalah semangat ideologi terhadap perjuangan kelas bagi kaum tertindas. Kenyataan ini dapat dilihat dari berbagai pemikiran realisme sosialis mulai dari Maxim Gorki, Lu Hsun, George Lukacs, bahkan sampai Pramudya Ananta Toer (Faiz Mansur dalam Mussaif, 2018).

Dalam upaya membangkitkan ideologi realisme sosialis, Pramoedya Ananta Toer menyuarakannya lewat tokoh yang hidup di kalangan keluarga Jawa santri, anak seorang haji yang taat beribadah, yaitu Midah. Gadis yang ditampilkan dalam novel itu awalnya sangat disayang oleh ayah dan ibunya, Haji Abdul dan istrinya. Perubahan sikap orangtua padanya bermula saat ia berusia sembilan tahun dan mempunyai adik lelaki, ia pun tidak diperhatikan bahkan cenderung dibiarkan. Karena merasa dibiarkan inilah, ia melawan dengan caranya sendiri seperti keluar rumah, pulang malam, hingga belajar menyanyi lagulagu keroncong. Sekalipun ayahnya mengharamkannya, tetapi ia tetap menikmati dan mencintai lagu-lagu etnis Jawa pengaruh Eropa.

Perlawanan terhadap sikap otoriter kaum patriarki, tampak pula pada sikap toko Midah pada suami yang sejak awal tidak disukainya. Setelah beranak satu, ia pun meninggalkan rumah suaminya dengan anaknya untuk mencari kebebasan. Ia tidak pulang ke rumah orangtuanya, tetapi mencari penghidupannya sendiri sebagai pengamen jalanan dan penyanyi keroncong. Di tengah kebebasannya itu pun ia jatuh cinta dengan seorang polisi yang bernama Ahmad. Keduanya saling mencintai tanpa ikatan resmi hingga ia pun mengandung anak Ahmad (Toer, 2003: 36). Kebebasan yang demikian ini, ia nikmati terbebas dari belenggu orangtua, suami, dan norma-norma sosial agama. Bahkan ia pun kelak akan memberi kebebasan pada anaknya nanti jika sudah terlahir di dunia. Sekalipun 
anaknya masih dalam kandungan, ia pun berpikir, bergumam, hingga terletup dalam doa untuk buah hatinya (Toer, 2003: 48).

Melalui novel Midah Simanis Bergigi Emas ini, pengarang tampak jelas memperjuangkan ideologi realisme sosialis dan memandangnya sebagai ideologi yang paling ideal. Dalam novel pengarang menunjukkan bahwa ideologi dominan, yakni feodalisme religis yang sangat negatif. Sebab, ideologi tersebut merepresi perempuan dengan cara-cara tidak adil dan otoriter.

\section{Simpulan}

Dari analisis hegemoni Gramscian terhadap novel Midah Simanis Bergigi Emas karya Pramoedya Ananta Toer dapat disimpulkan, bahwa novel itu mengungkapkan tiga ideologi yang kontras, yakni ideologi residual yakni ideologi kultural, feodalisme kultural, ideologi dominan yang mengusai (feodalisme religis), dan ideologi yang diperjuangkan (realisme sosialis). Karena kedua ideologi, yakni feodalisme kultural dan feodalisme religis dalam novel ini digambarkan sebagai budaya yang tidak ideal, maka pengarang menawarkan ideologi yang terbaik yakni ideologi realisme sosialis. Sebab, menurut pengarang, realisme sosialis itu mengusung kesetaraan gender dan menolak paham feodalime dan otoritarianisme. Jadi, dalam pertarungan ideologi inilah pengarang menunjukkan bahwa ideologi realisme sosialis inilah yang paling baik dan ideal, sebab mengusung kebebasan dan keadilan.

\section{Daftar Pustaka}

Faruk HT. 1994. Sosiologi Sastra Sebuah Pengantar. Yogyakarta: Pustaka Pelajar. https://faizmanshur.wordpress.com/2002/06/22/realisme-sosialis-2/

Muzakka, Moh. 1998. "Kuli Kontrak” Karya Mochtar Lubis: Analisis Hegemoni”. Dalam Jurnal Kajian Sastra. Vol. XX/1998.

Mussaif, Moh. Muzakka. 2014. "Pandangan Pramoedya Ananta Toer Terhadap Priyayi Santri: Kajian Sosiologi Sastra terhadap Novel Gadis Pantai. Dalam Prosiding 
Seminar Internasional PIBSI XXXVI "Membangun Citra Indonesia di Mata Internasional Melalui Bahasa dan Sastra Indonesia" diselenggarakan oleh Universitas Ahmad Dahlan Yogyakarta.

2018. Beginilah Meneliti Sastra. Semarang: Sint Publishing.

Thohir, Mudjahirin. 2013. Multikulturalisme: Agama, Budaya, dan Sastra. Semarang: Gigih Pustaka Mandiri.

Toer, Pramoedya Ananta. 2011. Gadis Pantai. (cetakan ke-7). Jakarta: Lentera Dipantara.

Ratna, Nyoman Kutha. 2004. Teori, Metode, dan Teknik Penelitian Sastra. Yogyakarta: Pustaka Pelajar.

Siminto. 2008. "Novel Gadis Pantai Karya Pramoedya Ananta Toer: Analisis Struktural Levi-Straus". Dalam Jurnal Studi Agama dan Masyarakat. Vol. 5, No.1. Juni 2008.

Wellek, Rene dan Austin Warren. 1990. Teori Kesusastraan. (diindonesiakan oleh Melani Budianta). Jakarta: Gramedia. 